Payments for ecosystem services schemes: project-level insights on benefits for ecosystems and the rural poor

Gabrielle Kissinger, Caitlin Patterson and Henry Neufeldt

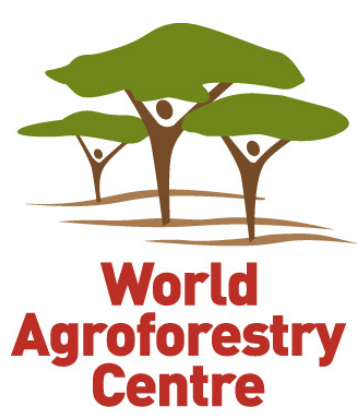




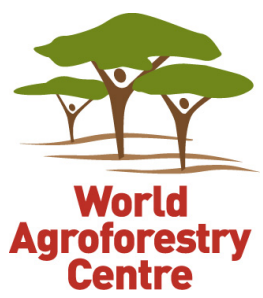

LIMITED CIRCULATION

Correct citation: Kissinger G, Patterson C, Neufeldt H. 2013. Payments for ecosystem services schemes: project-level insights on benefits for ecosystems and the rural poor. ICRAF Working Paper No 172, Nairobi: World Agroforestry Centre http://dx.doi.org/10.5716/WP13001.PDF

Titles in the Working Paper Series aim to disseminate interim results on agroforestry research and practices and stimulate feedback from the scientific community. Other publication series from the World Agroforestry Centre include Technical Manuals, Occasional Papers and the Trees for Change series.

Published by the World Agroforestry Centre

United Nations Avenue

PO Box 30677, GPO 00100

Nairobi, Kenya

Tel: +254(0)20 7224000, via USA +1 6508336645

Fax: $+254(0) 207224001$, via USA +1 6508336646

Email: worldagroforestry@cgiar.org

Website: www.worldagroforestry.org

(C) World Agroforestry Centre 2013 Working Paper No. 172

The views expressed in this publication are those of the author(s) and not necessarily those of the World Agroforestry Centre.

Articles appearing in this publication may be quoted or reproduced without charge, provided the source is acknowledged. No use of this publication may be made for resale or other commercial purposes.

All images remain the sole property of their source and may not be used for any purpose without written permission from the source.

The geographic designation employed and the presentation of material in this publication do not imply the expression of an opinion whatsoever on the part of the World Agroforestry Centre concerning the legal status of any country, territory, city or area or its authorities, or concerning the delimitation of its frontiers or boundaries. 


\title{
THE AUTHORS
}

\author{
Gabrielle Kissinger Lexeme Consulting \\ Telephone: +1 604 346-6474 \\ E-mail: gabrielle@lexemeconsulting.com \\ Caitlin Patterson World Agroforestry Centre (ICRAF) \\ Telephone: +254 207224000 \\ Henry Neufeldt \\ World Agroforestry Centre (ICRAF) \\ Telephone: +254 207224000 \\ E-mail: h.neufeldt@cgiar.org
}




\section{TABLE OF CONTENTS}

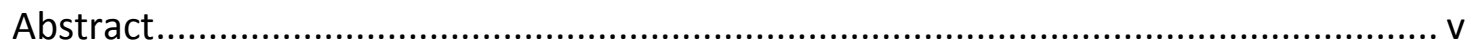

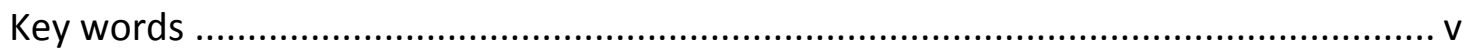

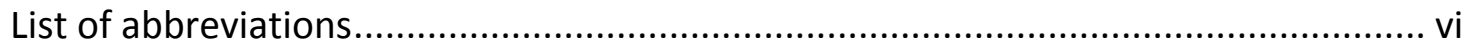

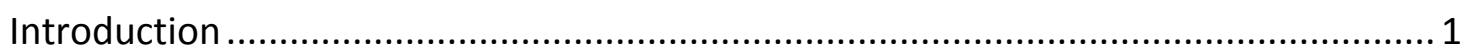

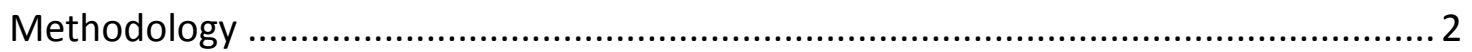

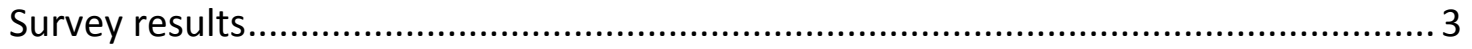

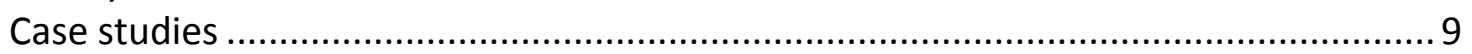

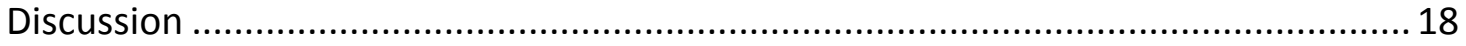

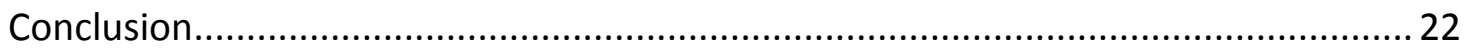

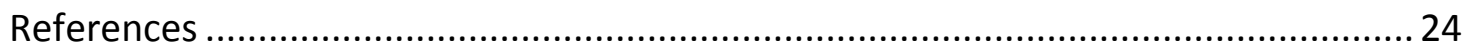




\begin{abstract}
Payments for ecosystem services (PES) provide a market-based instrument to motivate changes in land use that degrade ecosystem services. This investigation sought to better understand how effective PES schemes are in meeting the goals of safeguarding ecosystem services, while also benefitting local livelihoods and ensuring pro-poor outcomes. Based on an internet survey of 36 PES projects, including water- biodiversityand carbon-leading attributes, and analysis of a sub-set of nine case studies, we explore a range of insights and commonalities between projects. Findings indicate that in most cases non-financial benefits in the short-term lead to longer-term financial benefits for landholders, most often as yield increases, future harvest revenue, and access to markets for products. Many projects are not quantifying the full range of ES benefits they are providing. However, full compensation for these benefits is not necessary to safeguard the environmental services. Market mechanisms are an imperfect means of pricing the value of ecosystem services, particularly when enabling policies do not exist or are not consistent (e.g. policies committing to greenhouse gas emission reductions). While national-level PES schemes (e.g. REDD+) share many similarities with project-scale PES schemes, they fundamentally differ in their ability to deploy a full suite of incentives, policies, and regulatory interventions in order to meet their domestic programme goals, thus addressing equity and efficiency needs.
\end{abstract}

Keywords: Payments for ecosystem services, financial incentives, stewardship 


\section{LIST OF ABBREVIATIONS}

CCBA Climate, Community \& Biodiversity Alliance

CDM Clean Development Mechanism

CER Certified Emission Reductions

CliPAD Climate Protection through Avoided Deforestation

CSR Corporate Social Responsibility

DRC Democratic Republic of Congo

ES Ecosystem Service

ESVD Ecosystem Service Value Database

FCPF Forest Carbon Partnership Facility

FONAFIFO Fondo Nacional de Financiamiento Forestal

FPIC Free Prior and Informed Consent

GHG Greenhouse Gas

IISD International Institute for Sustainable Development

NGO Non-Governmental Organization

NTFP Non-Timber Forest Products

PDR People's Democratic Republic

PES Payment for Ecosystem Services

PINC Proactive Investment in Natural Capital

REDD Reducing Emissions from Deforestation and Forest Degradation

TEEB The Economics of Ecosystems and Biodiversity

UN United Nations

US\$ United States Dollar 


\section{INTRODUCTION}

Over the last 10 years, there has been a significant increase in private and public sector activity to explore and adopt market-like instruments that value ecosystem services with the intention of encouraging changes in degrading land use practices. Persistent problems of management and governance of ecosystem services frequently stem from poor information and institutional failures, with markets and systems of economics and accounting often providing the wrong incentives (TEEB, 2010). Therefore, efforts to value ecosystem services, and incentivize their conservation, seek to correct market failures, and seek to implement measures that may be more efficient and cost-effective than traditional command and control regulation.

The value of ecosystem services (ES) is difficult to ascertain. The most comprehensive global effort to determine the monetary value of ecosystem services provided by 10 primary biomes globally is derived from the Ecosystem Service Value Database (ESVD) and is a useful tool for evaluating the differences between ecosystem service values, on an International \$/ha/year basis (deGroot et al, 2012). However, markets largely define ES valuations on a willing seller/willing buyer basis. Ecosystem Marketplace estimates that global annual market size for biodiversity ecosystem services is US\$ 2.4-4.0 billion at minimum (Madsen et al, 2011). Ecosystem Marketplace identified 288 payment for watershed services and water quality trading programmes in 2008 , though the transaction value of these (US\$ 9.3 billion) pales in comparison to the value of functioning hydrological systems for people and nature. The rapid increase in compliance and voluntary greenhouse gas (GHG) markets in the last 10 years has influenced how governments, businesses and communities value climate change risks and impacts. However, a global agreement with binding commitments to reduce GHGs has not yet been reached. Even in the absence of major regulatory drivers, voluntary carbon markets related to ecosystem services were US\$236 million ${ }^{1}$ in 2011 (adapted from Peters-Stanley and Hamilton, 2012) and increase yearly. However, most ecosystem service value is outside the market and best considered as non-tradable public benefits (deGroot et al, 2012).

The defining characteristic of a payment for ecosystem services (PES) approach is that external ES beneficiaries make direct, contractual and conditional payments to local landholders and users in return for adopting practices that secure ecosystem conservation and restoration (Wunder, 2005). In essence, ES providers are compensated for their efforts to safeguard ecosystem services, thus ensuring their ongoing provision. Many ecosystem services originate from rural regions in developing countries where many of the world's poor are located, thus holding potential for PES schemes to benefit the rural poor. This research investigation sought to better understand if PES schemes have been successful in meeting the goals of safeguarding ecosystem services, while

\footnotetext{
1 Based on portion of offset types related to ES services. The Ecosystem Marketplace Carbon Markets 2012 report records overall voluntary carbon market value in 2011 as US\$ 576 million. By only including afforestation/reforestation, REDD+, biomass/biochar, clean cookstoves, forest management, large hydro and run-of-river hydro, we estimate US\$ 236 million.
} 
also benefitting local livelihoods and ensuring pro-poor outcomes. The following key questions guide this investigation:

1) How do experiences differ between water, biodiversity and carbon PES projects?

2) How important are benefits or payments in achieving ecosystem service and propoor outcomes?

3) What do the results and case studies tell us about mechanisms and key conditions for scaling up beyond the project level to sub-regional and national schemes (e.g. REDD+)?

\section{METHODOLOGY}

Between May and June 2010, an internet survey designed to gather information about PES projects was distributed through several listservs maintained by the International Institute for Sustainable Development (IISD). It comprised 17 questions posed to learn the logistics of PES schemes, seven of which were multiple choice and 10 of which were open-ended responses. The objective of the research was to gather information on as many PES projects as possible in order to close information gaps regarding their experiences in relation to benefits to the providers of the ES, benefit sharing, project logistics, as well as more general information on challenges and opportunities.

Of the 99 responses received, 36 projects were evaluated after omitting those that did not meet the definition of PES, did not contain enough information or were duplicate responses. Further, three national programmes were not included, since responses did not include enough information to compare these programmes to each other or projects in other countries.

Survey results match three of the four ES types defined by Wunder (2005): a) carbon sequestration and storage, b) biodiversity protection, c) watershed protection. Wunder describes a fourth, landscape beauty, which one project cited as a project attribute, although scenic values and landscape beauty were not the basis for ES payments. Ninety-two per cent of projects are in developing countries. Results from the surveys are summarized in Section 3, below. A further subset of these was selected for in-depth information gathering by interviewing the project contact (in most cases a project proponent). Interviews occurred in mid-2011, and transcripts of the interviews were drafted. These nine respondents were chosen as they represented a broad cross-section of PES project types, sizes and locations, in addition to providing detailed information about their projects in the original survey. An analysis of the case studies was made in late-2012, and these results are summarized in Section 4, below. 


\section{SURVEY RESULTS}

This section details survey respondent data for 36 PES projects. Twenty (20) projects are located in Africa, seven in Asia, six in Latin America, two in North America, and one in Australia. Survey results of all projects are broken into the following ecosystem service (ES) categories - water-, biodiversity- and carbon-leading projects. Of the 36 projects, 21 are carbon-leading, 13 are biodiversity-leading, and 12 are water-leading. Forty-four per cent of the projects contain more than one ES as a priority. The projects are in varying stages of implementation: $44 \%$ of the projects were fully functional at the time of the survey, $21 \%$ were in the planning phase, $29 \%$ were in the pilot phase, and $6 \%$ were completed.

\section{Water}

Most of the 12 water ES projects reviewed are payment for watershed services projects and three are agriculture or grassland projects. Five include biodiversity environmental services as well as water, and four identify carbon in addition to water. Though survey questions did not elicit responses on whether projects sought to compensate providers for multiple benefits or stack ES payments, it appears that none were. Nine of the projects are in Africa, two in Asia and one in Latin America.

Source of payments: Of the water-leading schemes, half are funded primarily through donors, as they are pilots, and not yet fully functional PES. Many of these projects seek financial contributions from individuals, companies or international markets, such as voluntary carbon markets. Only three of the 12 sought compensation through public agencies.

Types of benefits/payments: Of the kinds of benefits given to the providers of the ecosystem services, only three projects seek to, or are making payments to ES providers, with one project paying US\$ 800 per hectare over a 10 year period based on meeting targets, another offering cash vouchers to be used in local shops, and a third offering grants and loans. Most benefits to ES providers are in the form of services, especially professional support, capacity building and technical assistance, which was the case in 11 of the 12 projects. Half of the schemes relied on benefits to ES providers being made with in-kind contributions, such as fertilizers, manure and seeds.

How benefits/payments are distributed: The most common distribution mechanisms for ES benefits is via community-based institutions (e.g. associations, farmer groups) and NGOs, used by seven of the 12 reviewed. Only four schemes make direct payments to beneficiaries. While a few schemes rely on private organizations (e.g. a company or project developer), three use an entity or agency specifically set up for purposes of payment distribution. Half of the schemes found it necessary to create a new group/organization to distribute the benefits to the ES providers. Four of the 12 projects 
seek to distribute benefits directly to households or landholders/users and four schemes distribute on a village or community basis.

Nature of PES contracts: The nature of the contracts range from voluntary buyer-seller agreement reviewed and renewable after every year to longer-term partnerships that identify goals and milestones achieved.

Challenges and conflicts: The main challenges encountered varied between projects, with most either citing financial constraints (e.g. lack of funding or lack of accountability mechanisms), institutional constraints (e.g. lack of understanding by government agencies, limited human resources), or behavioural constraints (e.g. shifting longstanding practices such as charcoal use). Two projects identified weather as a key challenge. On the specific conflicts that projects have experienced, most involved conflicts between user groups (e.g. some communities receiving benefits while others do not) and one project reported frustration by fishermen downstream that farmers who pollute upstream (with fertilizers and pesticides) receive incentives and payments.

\section{Biodiversity}

Thirteen projects include biodiversity as a primary ecosystem service provided in the scheme. Of the 13, only three include biodiversity as the only ES, with the majority of projects (eight projects) also identifying carbon as an ES. Four projects also include water as an ES. Five are located in Africa, three in Asia, three in Latin America, one on a First Nation traditional territory in Canada and one in Australia. Two projects are fully functional, one is completed, and the rest are in various stages of development.

Source of payments: Currently, seven of the 13 are, or anticipate, sourcing payments from individuals, corporate CSR programmes, companies complying with regulations, carbon markets, multilateral programmes such as the UN-REDD Programme and FCPF, and donors for project start-up costs and pilots. These seven projects are seeking funds from a minimum of three sources and a maximum of five sources, indicating revenue streams that are far more diverse than water- or carbon-leading projects.

Types of benefits/payments: Only one project anticipates revenue-only benefits to ES providers, with payment based on provision of an "annuity" payment equal to the discounted net-present value of foregone timber harvests. All other projects seek to provide services, in-kind contributions and other benefits such as micro-finance loans, technical assistance, and marketing assistance for ecotourism or non-timber forest products.

How benefits/payments are distributed: The preferred distribution mechanism is via non-profit organizations and community-based institutions, acting as an intermediary between payers and providers. This may also reflect the majority of projects offering service and in-kind benefits, which carry different capacity requirements than managing 
financial transactions. Only three of the 13 projects seek to distribute benefits directly to beneficiaries, and two will rely on a private organization.

Nature of PES contracts: The nature of biodiversity-leading ES contracts follows a range of options, with varying degrees of detail and obligations among parties. Most other projects rely on binding contracts directly with individual providers, with rights and responsibilities, and timelines for payment. Three feature community-level or organization-level agreements; one involving a union comprising cooperatives, one based on an aboriginal community reaching an agreement with a Province, and another based on use of traditional or indigenous knowledge for conservation practices, with no formal contract between providers and buyers, and external agencies only supporting in-kind and service contributions such as information, education and training. One Plan Vivo-verified project has contracts at individual and community levels-with individual contracts with farmers for agroforestry activities, while contracts with communities cover REDD activities, and both conform to national legal standards.

Directly related to findings on contracts, the existing or planned benefits/payments are made largely to households. However, only two projects directly benefit communities, with payments supporting collective interests. The projects sharing benefits with households are characterized as follows:

- Two projects base rewards on income from yields going to farmers (e.g. farmers plant trees, then get the benefit of harvesting nuts, coffee or NTFPs. One of these projects will also seek REDD+ payments in the future. The reward to households/farmers in another project is actually the cost-savings each household has by not having to buy charcoal brought in from neighbouring districts.

- Payments to individuals/households are largely based on performance, such as number of trees planted or conservation practices adopted. Of the two projects (located in Nicaragua and Mozambique) that pay directly to households and disclosed how much they are currently paying, the amount ranged from US\$120 to US\$ 155 per year, with one project lasting seven years, and the other 10 years.

- One project starts with landholders expressing interest to participate in a programme, followed by a technical officer field visit to identify management practices that are codified in an agreement. The landholder then uses that agreement as the basis for a bid on what payment they should receive for their efforts over five years. Successful bids are those that show best environmental value for money, with landholders subsequently receiving periodic payments for their management activities.

Challenges and conflicts: Challenges range from financial, technical to political ones. A lack of transparency and accountability in distributing financial benefits, and taking risks in distributing benefits before carbon revenues are in-hand in order to gain landholder support and compliance, were cited. Technical challenges include translating carbon 
accounting methodologies to the project sites, and establishing data and monitoring systems (both human capacity and technical capacity), which require continuous refinement. Political challenges include the lack of consensus and agreement at international level on compliance mechanisms for reducing greenhouse gas emissions. Project developers report increased risk on their part in order to cover costs bringing landowners into schemes without knowing whether longer-term costs and commitments can be covered through carbon markets. Political challenges also occur at local and project levels, with landholders not fully understanding the schemes, valuing short-term payments or benefits over longer-term project goals and value to communities and ecosystems.

Conflicts between different stakeholders include disagreeing over access to benefits or inclusion in the scheme, difficulties in ensuring equitable benefit-sharing, agriculture expansion and resource extraction (including trophy hunting and mining). Three of the projects report experiencing no conflicts so far.

\section{Carbon}

Over half of all projects reviewed (21 out of 38 ) are identified as carbon-leading PES initiatives, with two in developed economies and the remainder in emerging economies. Eight are in Africa, five in Latin America, three in Asia, and one in North America. Almost half (10) of the projects are avoided deforestation or afforestation projects (or both), another eight contain a secondary biodiversity focus (thus, referenced in the above section), and three also include water attributes such as flood and erosion control and riparian protection. One of the projects also seeks increased carbon storage by promoting fuel-efficient stoves. One project lists scenic values as an important project attribute, however the PES scheme is based solely on carbon offset sales. Thirteen of the 20 identified are fully functional schemes, while four are in the pilot stage and another four in the planning stage.

Source of payments: Of the 13 projects that are fully functional, nine cite revenues coming from corporations (e.g. CSR programmes), seven receive revenue from international or national carbon markets, and only four receive funds from individuals (e.g. via carbon offset company sales). Eleven rely on donor contributions, particularly in project development and pilot stages.

Types of benefits/payments: Twenty of the 21 carbon-leading PES projects also seek to provide benefits to ES providers in the form of services, most commonly in the form of capacity, technical and professional support (15 projects provide business and microenterprise development, financial services, technical support and advisory services on alternative livelihood strategies). Five projects identify education as benefits to be provided. Four projects provide investments in community projects and social services. Nine projects also seek to provide in-kind benefits, such as agricultural and agroforestry materials, infrastructure assistance, and marketing and promotion in foreign markets. 
One REDD project also provides one staff nurse at the project clinic and laptops for the local schools.

How benefits/payments are distributed: Of the carbon schemes seeking to distribute benefits as payments given to the providers of the ecosystem services, five projects base payment on the amount of carbon sequestered, with payments ranging from US\$ 2 to US\$ $7 \mathrm{tCO}_{2}$. Four projects base payment to landholders on a percentage of carbon credit sales. Another will base payments on opportunity costs. These projects are predominantly avoided deforestation initiatives, and could be selling credits based on ex-post and ex-ante emissions, though two of them specify that payments must be based on targets and emissions reduction goals being met ex-ante. Afforestation and reforestation projects favour basing payments on the number of trees that survive, reaching certain thresholds, or simply a dollar per hectare payment based on meeting targets. Two projects have no link between the amount of carbon sequestered and payments to ES providers; one bases payments on premium prices negotiated for coffee produced from the forest, and another provides new jobs in the area (although this large REDD+ project is known to the author and it is unlikely the existing conservation project and new avoided deforestation strategy for the area will provide many jobs that can out-compete the rapidly expanding mining sector, which is a major cause of deforestation in the region).

Distribution mechanisms: Mechanisms relied upon to distribute payments to ES providers favour the use of non-profit organizations as intermediaries, as half of carbonleading projects reviewed rely on non-profits for distribution, with two of those projects setting up a new entity specifically for that purpose. Community-based institutions such as associations and farmer groups, private organizations such as a company or project developer, and direct payments to beneficiaries are all equally favoured as a means of benefit distribution.

Nature of PES contracts: In 10 of the 20 carbon projects, the PES contracts are negotiated agreements between landholders and project developers. However, seven projects involve customary land tenure rights by land users. In these cases, agreements are made with community organizations, cooperatives or chiefs, and the distribution of benefits is the responsibility of those entities (and the details of any subsequent agreements between those entities and individuals is unknown, based on the data inhand). Indications are that in general, agreements specify the responsibilities of both parties, milestones and timelines. Only one project indicated that the contract detailed the percentage of revenues to be received by each party involved, such as developers, brokers and communities/landowners. In areas with undefined or customary use rights, it is unclear how much detail exists in contracts and therefore how much local ES providers can gain access to information on performance of the project and their relative share of benefits. One project seeks to create use agreements for conservation and restoration between the national government and villages using forests. However, it has not yet linked payments to carbon markets due to uncertainty in their efficacy. 
Challenges and conflicts: Development and approval of methodologies, adapting methodologies to specific project sites and developing monitoring and data systems cited by five projects as time consuming and expensive. Four projects cite uncertainty in carbon markets and low carbon prices as a challenge, which in most cases relates to parties taking on significant financial risks or requiring development assistance funds to cover significant project development costs. In two cases, the challenge of covering start-up costs is compounded by a need to simultaneously get payments out to ES providers, to ensure their commitment to the project. One southeast Asian avoided deforestation scheme cites uncertainty in carbon markets as the reason for the central government not reaching agreements with local land users about a benefit sharing mechanism.

Further, large non-permanence and leakage buffers, which are common in project-level carbon initiatives result in fewer benefits or payments reaching the ES providers, after project development, monitoring and transaction costs are covered. The authors' experience with other projects across a range of standards in the voluntary market indicates a range of between $15-20 \%$ as a permanence buffer, plus $20-60 \%$ as a leakage buffer being held-back. One project reported a permanence buffer of $60 \%$.

Three projects cite competing demand for land as a key challenge to keeping landholders and users committed to the scheme. One project identified tenure issues as the primary challenge, while another cites complications of working with many landholders on mixed species tree plantations, particularly as residents must be continuously trained since there is significant turn-over among residents.

Conflicts identified tend to occur at local levels, and relate to who accesses benefits and who does not. One project developed over eight years has seen tension between those in the scheme having to enforce their interests against those who would rather collect firewood for charcoal or expand agricultural production. While local-level enforcement has been essential to project success, it is also reported that trust between the project developer and ES providers formed due to payments being made as promised, and tree mortality has now decreased. Another project cites the increase in land value as a result of the project on previously marginal lands as the reason for new conflicts over rights to these lands. Thus, local village chiefs are crucial in resolving these conflicts. Another project cites the difficulty of having government authorities acting on behalf of communities, as complicating negotiations on equitable benefit sharing.

One project on communal land has overcome potential conflicts over ES and extractive resources revenues by establishing a farmer-led cooperative of 227 farmers. All benefits from the sale of timber and NTFPs belong to the land users. However, revenues from carbon credit sales are considered the property of the society of farmers, with each farmer holding shares in the society on the basis of the 0.05 -hectare units of land they commit to the project. Further, the regional forest department, acting as the project 
developer, cannot claim any share of the revenues from carbon credit sales, and costs for project development were raised separately.

\section{CASE STUDIES}

The nine case studies chosen provide further insights into the functionality of PES schemes, and consist of a subset of the survey responses. All the case studies are in emerging economies, including: Costa Rica, Democratic Republic of the Congo (DRC), two in India, two in Kenya, Lao PDR, Mozambique, and Nicaragua. Seven of the case studies are carbon-leading and two are watershed services projects. The interviews with project representatives provide a range of insights and commonalities between projects, with key findings below.

\section{The importance of financial benefits to change business-as-usual activity}

Many case study projects attribute the financial benefits to motivating change beyond business-as-usual. In the Cooperative Afforestation CDM Pilot Project on Private Lands Affected by Shifting Sand Dunes in Sirsa, Haryana, India, landholders were enticed by payments and the promise of accrued benefits, which was the leading factor in the society being formed. Similarly, farmers skeptical of increased crop yields were nevertheless compelled to join the Sofala Community Carbon Project due to financial benefits, particularly as project developers front-end loaded the payments to farmers (30\% of projected total revenues). The Limay Community Carbon Project also front-end loaded payments and offered interest-free loans (with due diligence carried out to ensure activities are based on real needs and related to the size of their project), as an enticement. The Sofala Community Carbon Project found that the business relationship formed between buyer and seller also motivated landholders to take their responsibilities seriously, since failure to meet performance benchmarks would result in loss of benefits and cancellation of the contract. But offering front-end loaded payments and benefits comes with risks for the project developers, as they struggle with balancing short-term demands (e.g. paying landholders, implementing GHG mitigation activities) with the long-term revenue needs of a project in uncertain carbon markets, political risks, and uncertainty on whether or not landowners will adhere to project goals.

\section{Non-financial benefits provide future financial benefits}

In eight of the nine case studies, non-financial benefits were offered at the start or understood to accrue over time. In all of these cases, the non-financial benefits are or could be of equal or greater value than the payments, though in two early stage case studies estimation of the non-financial benefits appeared to be difficult. The experience of the Western Kenya Smallholder Agriculture Carbon Finance Project demonstrates that carbon revenues from reducing GHG emissions in agriculture are small, particularly 
after transaction and implementation costs are covered. Thus, the carbon revenue is a small incentive around which other benefits can be offered, such as advisory and financial services, farm enterprise development, and improved farm income from increased yields. Similarly, the Equitable Payment for Watershed Services project in Kenya found that although ES payments are not equivalent to opportunity costs, it is an incentive to change farm practices that are more beneficial to the farmers, thus the non-financial benefits are significant.

Once landholders were brought into ES schemes, their appreciation of non-financial benefits increased. In most cases non-financial benefits in the short-term lead to longerterm financial benefits for landholders, most often as yield increases, future timber or NTFP revenue and access to markets for products. Farmers in the Western Kenya Smallholder Agriculture Carbon Finance Project received low payments from carbon offset sales. However, there would be longer-term financial benefits through increased soil fertility, increased yields, and longer-term farm productivity. Farmers and residents involved in the Carbon Sequestration and Alternative Energy in Tshilenge, DRC project receive shorter-term payments from farm yields. However, the longer-term benefits of decreasing dependence on charcoal imports from neighbouring districts could significantly increase household income. Farmers in the Sofala Community Carbon Project realized increases in crop yields, resulting in surpluses sold at market and noticeably improved local standards of living. While initial payments enticed farmers to join the Limay Community Carbon Project, future revenues from the fuel wood and pole timber sales will be far greater than ES payments after five years. Some of those interviewed indicate the long-term financial benefits to landholders as being significant enough that if the ES payments stopped, the improved practices would continue.

\section{Tenure}

While secure access to tenure is widely considered to be a pre-condition of PES schemes, three of the nine cases require contracts between ES buyers and communities or associations, since project areas consist of communal lands or lands without clear tenure. The Sofala Community Carbon Project contains a mosaic pattern of forest areas that are the property of either communities or individuals, so contracts are entered into with both individuals and community associations. Though the Climate Protection through Avoided Deforestation (CliPAD) initiative in Lao PDR is still in the pilot stages, it is anticipated that agreements would be directly with communities, as communal ownership of resources is most common in the Laotian context. Some project developers assist individuals in communities to obtain more formal land tenure rights. One project developer noted that communal ES schemes can work, but could also increase incentives for individuals to free ride, thus emphasizing the need for strong community planning and monitoring in those areas. 


\section{Gap between the value of ecosystem services and what ES providers are compensated for}

PES scheme designs must account for what incentive and compensation levels landowners need to adequately steward resources, and what ES buyers are willing to pay for them. Many projects are not quantifying the full range of ES benefits they are providing, and full compensation for these benefits is not necessary to safeguard the environmental services. Though the Costa Rican avoided deforestation project relied heavily on forest carbon offset sales, a benefit not monetized was safeguarding water quality and aquifer recharge, benefiting 150,000 local inhabitants.

Determination of a buyer's willingness to pay can be based on negotiated levels or market dynamics. Seven of the projects rely on carbon markets for a portion or a majority of project financing. Without significant international or national GHG emission cap-and-trade or reduction commitments in place, evidence from these projects indicates projected revenues are much lower than expected. One project reports that of 1.1 million tons of carbon offsets generated from project activities, only 250,000 have been sold (about $20 \%$ of offset potential). Prices paid to participating farmers in that project are fixed, stretching the project developer to cover costs while delivering payments out to farmers. Another project reports purchase agreements on 150,000 $\mathrm{tCO}_{2}$, although their sequestration potential is 1.2 million $\mathrm{tCO}_{2}$. Given these financial challenges, one project developer seeking to make the business model work in new projects has changed perspective and is now focused on identifying single blocks of forest, $>100,000$ hectares, for REDD+ purposes, thus abandoning the higher transaction costs involved in dealing with individual landowners. One well-established carbon project reported adequate carbon credit sales, to cover costs and ES payments, with over half of credit revenues going to ES providers and a smaller, but still significant portion, covering project development, transaction and monitoring costs.

While voluntary carbon markets provide a significant source of global ES revenue, diversifying ES revenue streams and spreading risks across multiple projects can help projects overcome common hurdles such as high start-up costs and dependence on fluctuating markets (reference). The Costa Rican government PES programme, FONAFIFO, takes some of the risk off project developers and communities by providing diversified revenues to support the PES programme. Revenues come from a gasoline tax, water usage fees, development assistance funds and carbon offset sales, and the programme is administered by the government which acts as an intermediary between landowners and funders/buyers. The Avoided Deforestation in Central Cordillera, Costa Rica project has benefitted from this, and the success of the project does not appear as vulnerable as other projects relying solely on offset sales. Further, the FONAFIFO consolidates satellite monitoring and inspection activities for this project and others.

The watershed services projects do not exhibit as large a gap between project potential and what providers are compensated for, since project financing is more localized and 
linked to downstream users, and transaction costs are lower than with carbon projects. The Equitable Payment for Watershed Services project in the Lake Naivasha catchment, Kenya links the horticulture and tourism industry and town of Nakuru, to ES providers upstream, resulting in a voucher transacted once every year. The improved food security and household income from non-financial benefits appear to be far more significant to ES providers than the value of the voucher. The Fair Deals for Watershed Services project in Madhya Pradesh and Himachal Pradesh, India appears to rely solely on an in-kind payment with very low transaction and monitoring costs, based on the simplicity of the agreement between upstream providers and downstream beneficiaries.

\section{The role of traditional power structures and community-level dispute resolution}

Project developers and ES buyers emphasize the importance of engaging both traditional and local power structures in order to build support for ES schemes and arbitrate disputes, which is critical to long-term project success. In cases of unclear or communal land rights, traditional and community leadership structures can be essential for defining institutional and benefit-sharing arrangements. In the Carbon Sequestration and Alternative Energy in Tshilenge, DRC project, local chiefs play a critical role in mobilizing community support for the project, overseeing commitments on communal lands, and ensuring trust and delivery of benefits and services during project implementation. In the Fair Deals for Watershed Services project in India, village councils played a major role in negotiating the agreement between upstream and downstream users, and defining terms and conditions. One of the critical conditions was the ability of downstream users to monitor the upstream ES providers. Monitoring was built into the agreement, allowing the lower village to access the upper one anytime, and to jointly review performance each year. Similarly, the Limay Community Carbon Project in Nicaragua found the importance of trust building within the community and among stakeholders crucial to project success. The Climate Protection through Avoided Deforestation (CliPAD) project areas are applying Free, Prior, Informed Consent (FPIC) with local communities to define project goals, and agreements will be with communities. Those case studies that developed their project according to the Plan Vivo methodology, which is a standard for designing and certifying community-based PES programmes, allow local landholders to largely define project activities, obtain community input, and promote social capital and local capacity over natural resource use.

\section{Importance of neutral third parties in benefit/payment distribution}

The role collective organizations or cooperatives can play in organizing many landholders and acting as an intermediary is critical. As mentioned in Section 3 on survey results, half of the carbon-leading projects rely on non-profits for benefit distribution, with two of those projects setting up a new entity specifically for that purpose, and many projects also relying on community-based organizations. Many ES buyers and/or brokers will not deal directly with ES sellers, thus intermediaries are 
crucial. Further, since most projects distribute multiple benefits beyond payments (most commonly technical assistance and in-kind contributions), there are efficiencies in using intermediaries as a distribution hub to lower transaction costs. Projects not doing this report having high costs in extension services, and in a few reported cases, the costs are significant enough to jeopardize the success of the project (especially as carbon prices are low).

One of the benefits to local landholders of community- or association-level agreements is the collective voice of landholders and group responsibility. Though each farmer in the Western Kenya Smallholder Agriculture Carbon Finance Project holds title to their land, the PES agreement is with the farmer group, so responsibility lies with the group to fulfill the obligation set out in the contract. Further, the farmer groups are important as distribution points for the other services the project provides, including being set up as farmer saving and loan associations, providing needed financial infrastructure for agricultural producers.

In the Fair Deals for Watershed Services project, the downstream irrigation-water users group (buyers) realized during the process of needs identification and valuation of the $\mathrm{ES}$, that they did not represent a large-enough set of users. By allowing more users to access irrigation, more surcharge could be collected and invested in the upstream catchment. This has led to increased availability of irrigation (and likely increased yields) for users downstream.

Collective organizations also help to overcome perceptions of risk on the part of landowners. In the Fair Deals for Watershed Services project in India, individual landowners were concerned about compromising their property rights and tenure by signing an agreement with a downstream village. Thus, the village development committee acted as an intermediary and the issue was resolved.

\section{Landscape and mosaic approaches: delivering financial and ecosystem service benefits}

Two projects offer insights into how landscape and mosaic land use project attributes relate to financial feasibility and overall success in safeguarding ecosystem services. In balancing high transaction costs with interventions needed to address slash and burn agriculture, the two components of the Sofala Community Carbon Project reinforce each other-i.e., the REDD component subsidizes the agroforestry component, which has higher transaction costs, but the agroforestry component enables the REDD+ component of the project to succeed, as it shifts local drivers of deforestation.

The Climate Protection through Avoided Deforestation (CliPAD) project in Lao PDR demonstrates a solid link between agricultural and REDD+ objectives. The initiative is focused on increasing soil fertility to support REDD objectives, in order to increase crop production in areas of shifting cultivation, applying a landscape level approach and thus 
linking improved agricultural methods and conservation goals directly in the ES contracts.

\section{Challenges faced}

Both survey and case study results indicate that the biggest challenge is financial, and given the high proportion of carbon-leading PES schemes, under-performing carbon markets and lack of greenhouse gas emission reduction enabling policies is of major concern. Under-performing markets lead to diminished funds ultimately reaching ES providers, after covering project costs (except in cases where contracts guarantee ES providers a fixed $\$ / \mathrm{tCO}_{2}$, rather than a percentage).

Five of the case study projects identify competing land uses, economic changes that distract landowners from project goals and changes in government policies as the biggest challenges. One project has already lost some of its benefits, since a new road was constructed above the project area, negating some of the benefits gained in decreasing erosion and siltation from shifting grazing. Three of the case study projects (almost half of those relying on carbon markets for revenues) identify the lack of development in compliance carbon markets and low carbon prices as their biggest challenge. Two case study projects cite building local capacity and staffing as critical challenges. Lastly, political stability is cited by the Carbon Sequestration and Alternative Energy project in Tshilenge, DRC as a critical challenge inhibiting their ability to raise necessary funds for the project, as well as disrupting agricultural cycles which further hinders the project, but more importantly, has a direct impact on local food security. It is unclear how projects are mitigating these last two challenges. 


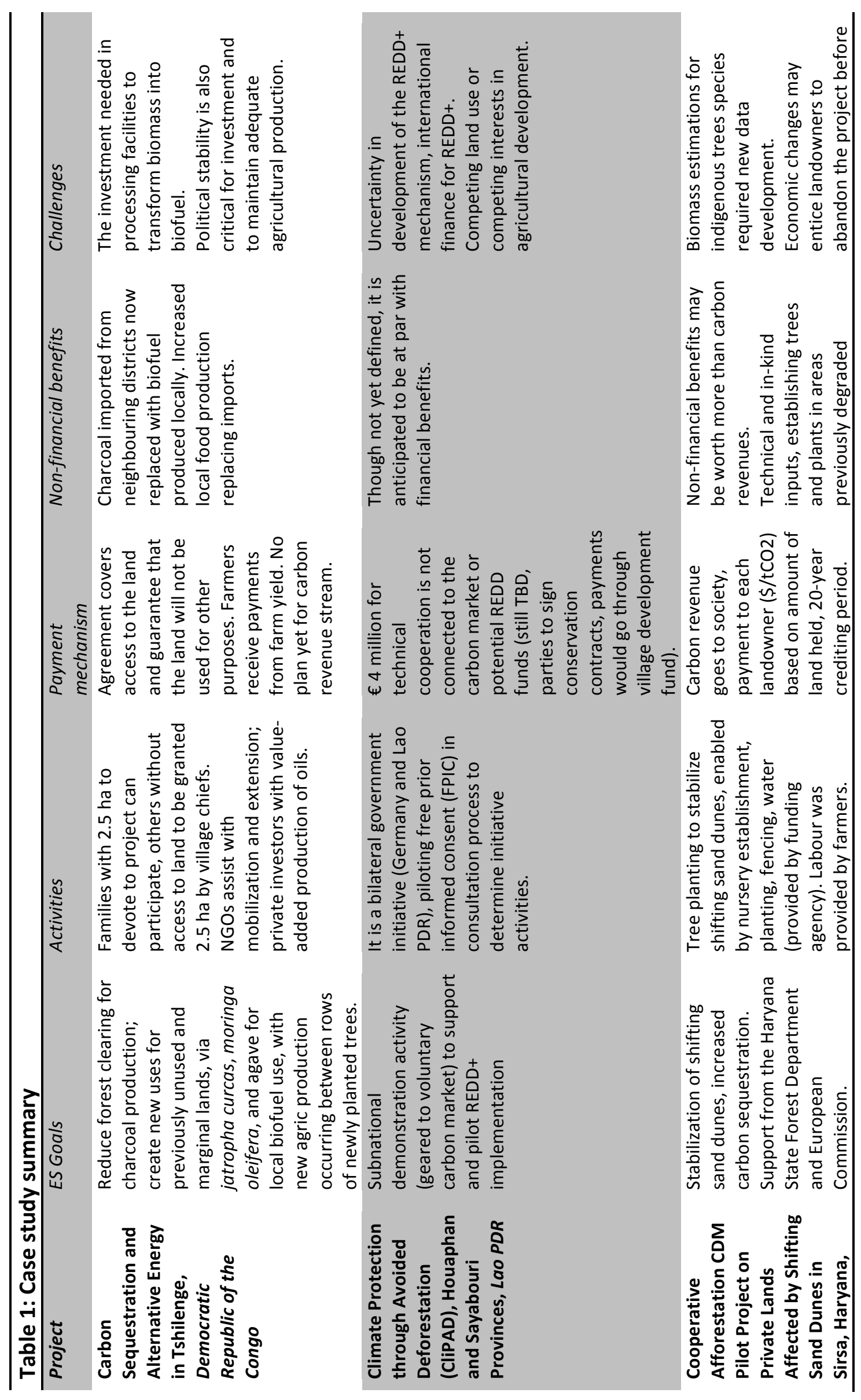




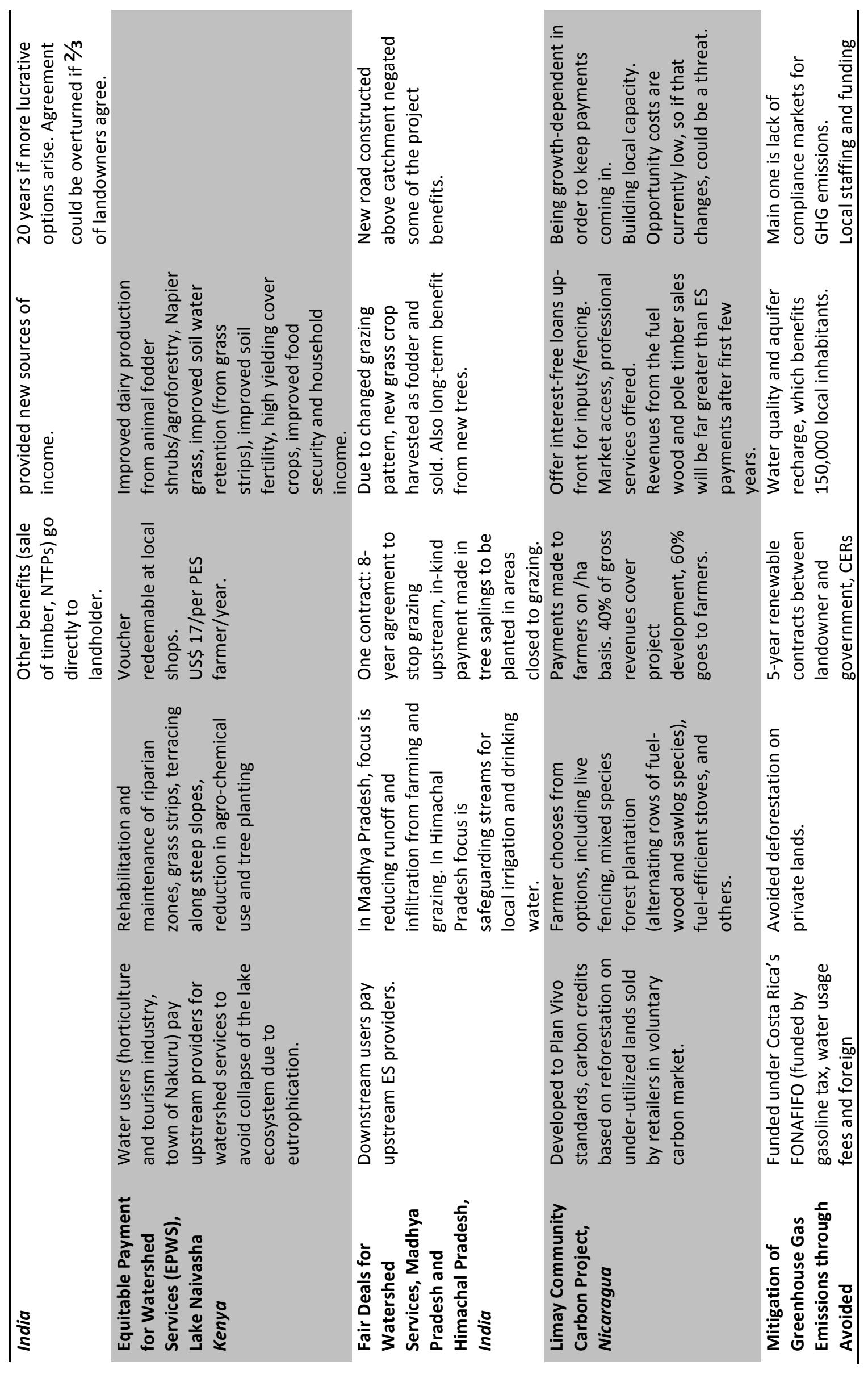




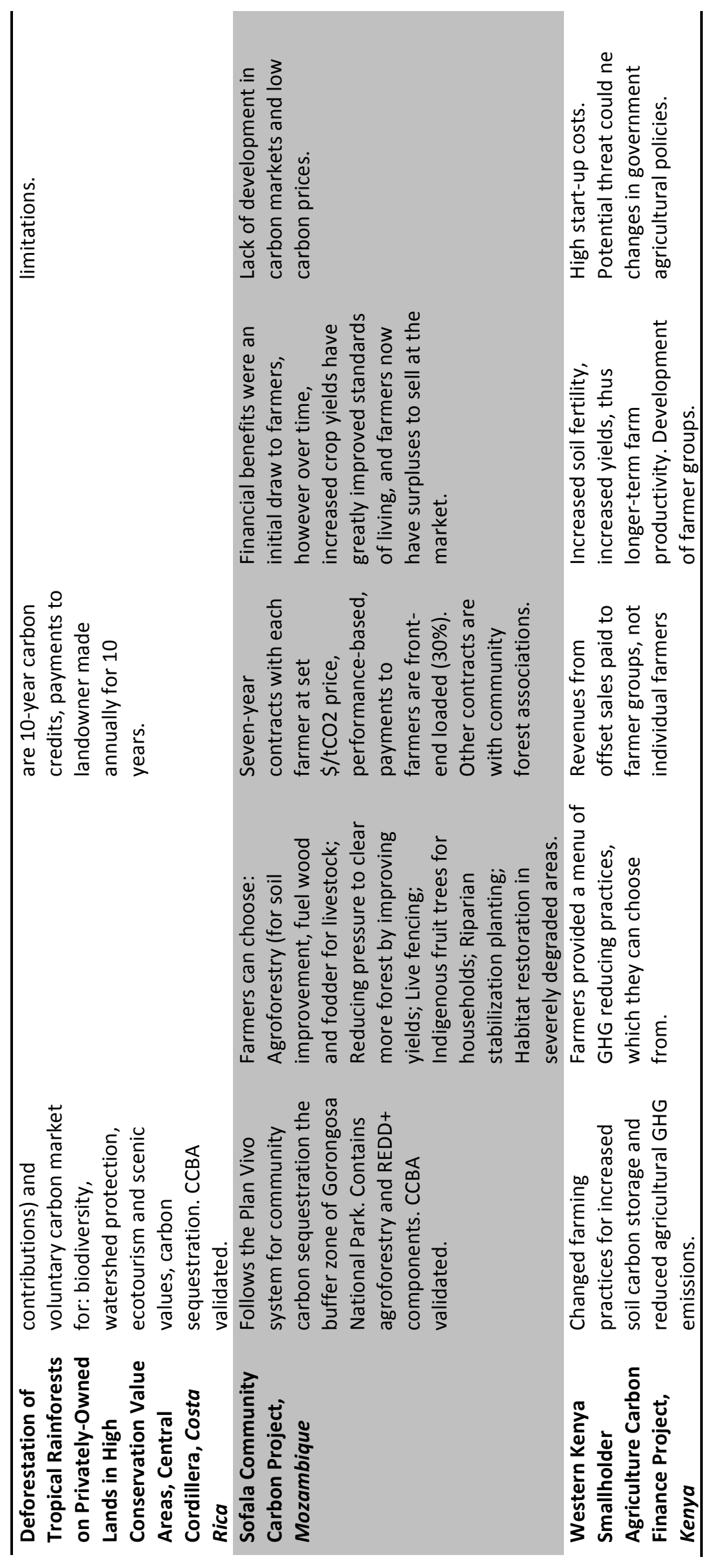




\section{DISCUSSION}

\section{How do experiences differ between water, biodiversity and carbon PES projects?}

Almost half of the projects surveyed contain multiple ES attributes, though the majority are carbon-leading. Despite the multiple ES attributes, projects largely rely on revenue streams from one ES, most commonly carbon sequestration. Thus, survey results do not indicate multiple ES attributes leading to the stacking of ES payments to ES providers. However, results indicate multiple ES attributes can have a positive impact on the ability to sell carbon offsets and attract donor funds.

The role of donor funds appears to be significant in incubating PES schemes. Waterleading projects receive a significant portion of funding from donors, as do carbon projects. While there is concern about the degree to which international and donor investment in PES schemes undermines their long-term financial sustainability (Murillo et al, 2011), the intent of donor funds appears to be to build capacity and mature projects so they can eventually leverage other sources; e.g. carbon projects maturing to the point to which they can tap into carbon markets and offset sales. Biodiversityleading projects contain revenue streams that are far more diverse than water- or carbon-leading projects, likely reducing their vulnerability to financial swings, though quantity of financing is still a key challenge.

ES providers access a range of benefits in each of the three project-types, ranging from direct payments to non-financial benefits and in-kind contributions. Based on survey findings, a quarter of the water-leading PES schemes pay ES providers, and the remainder rely on benefits such as services, and in-kind contributions. Similarly, biodiversity-leading PES schemes favour professional support, capacity building and technical assistance, as well as in-kind contributions. In contrast, carbon-leading PES favour payments directly to ES providers, and almost all projects also seek to provide capacity, technical and professional support benefits.

There is need to differentiate between the roles of both ES benefits and payments in influencing ES providers' land use management. ES benefits, such as non-financial benefits and in-kind contributions, can be targeted to support project goals, such as technical assistance for farmers to reduce nutrient loading into waterways. Payments, on the other hand, are unrestricted and the landowner's use of the funds may or may not further project goals. Further research could investigate how landowners use ES proceeds, and what effect this has on safeguarding ecosystem services. Generally, more quantitative causal analyses of PES effectiveness is needed, particularly since their use at local and national levels is on the rise (Greig-Gran and Porras, 2012; Pattanayak et al, 2010). 
Targeting is a useful tool in PES approaches for service buyers to select among sites or ES providers to maximize a scheme's operational and financial efficiency (Engel et al, 2008). These findings indicate that projects generally attune proportions of payments and benefits to project area circumstances and landholder needs as stewards. When targeting is based on threats to ecosystem services, the likelihood of additionality of the ES intervention is increased.

The role of neutral or third party organizations in the distribution of payments and benefits is important across all project types. Water-leading projects distribute benefits and services via community-based institutions. Biodiversity-leading projects favour benefit distribution via non-profit organizations and community-based institutions, likely related to the predominance of service and in-kind benefits. This requires capacity on the part of these organizations to distribute such benefits. While carbon-leading projects similarly favour non-profits for distribution, a significant amount of capacity needs (and overall project costs) lie with project developers (development and approval of carbon accounting methodologies, measurement and monitoring activities, etc.). As most case study projects distribute multiple benefits beyond payments, there are efficiencies in using intermediaries as a distribution hub, and it lowers transaction costs. Lowering transaction costs is especially important to minimize project vulnerability due to low carbon prices and other financial pressures. In cases where ES buyers are located far from the service provider (such as carbon projects), there is greater need to verify the effectiveness of PES so users can understand the benefits they receive from the resource (Fisher et al, 2010) and hence, transaction costs are higher. Further, transaction costs are an important determinant of participation rates of poorer households in PES schemes (Rios and Pagiola, 2009; Wunder, 2008).

\section{How important are benefits or payments in achieving ecosystem service and pro-poor outcomes?}

Case study results indicate that financial benefits are a critical enticement to change in land use practices and build commitment on the part of ES providers to steward resources. Further, survey results indicate and case study responses confirm that once landholders were brought into ES schemes, their appreciation of non-financial benefits increased. In most cases non-financial benefits in the short-term lead to longer-term financial benefits for landholders, most often as yield increases, future timber or NTFP revenue and access to markets for products, thus increasing incomes and pro-poor outcomes. Some case studies indicate the long-term financial benefits to landholders as being significant enough that if the ES payments stopped, the improved practices would continue. This may be more plausible in circumstances where landholders change land use practices that are privately profitable (Engel et al, 2008) and make practical sense (e.g., agricultural practices that improve soil fertility while lowering costs). However, in circumstances where there are competing land uses and/or development pressure is high, this may not be the case. Pattanayak et al. (2010) warn of the danger of equating the impact of PES with the area under PES contract, which confuses additionality with 
compliance. Further, survey results and case examples are less clear whether schemes are paying for changes that could have been adopted through other means-in essence explicitly considering the counterfactual (e.g. ES in the absence of the scheme)(ibid).

PES schemes encourage clarity and security of land tenure, a critical incentive for landholder stewardship of ecosystem services. One recent analysis of 100 empirical examples concludes that where incentives are tied to land-use-based duties and outcomes, security of land tenure is crucial to influence landholders' decision-making (Robinson et al, 2011). PES schemes reviewed are overcoming tenure barriers on communal lands or lands without clear tenure, by engaging in contracts with communities or associations. In some cases, project developers or NGOs help individuals in communities to obtain more formal land tenure rights.

Community- or association-level agreements promote the collective voice of landholders and encourage group responsibility, benefitting resource stewardship, while also providing a focal point for technical assistance and capacity building. Collective organizations also help to address risks (perceived or real) on the part of landowners to engage in ES schemes. Community-based intermediaries and traditional leadership structures are an important means of defining institutional and benefit-sharing arrangements, as well as a forum for community-level dispute resolution.

Determining compensation levels to landholders in order to adequately steward resources is important, and full compensation for all ES services is not necessary to safeguard the environmental services. However, accounting for the full value of ecosystem services helps users understand the value of benefits derived from ES and future potential costs if those ecosystem services are degraded or non-functioning. Market mechanisms are an imperfect means of pricing the value of ecosystem services, particularly when enabling policies do not exist or are not consistent (e.g. policies committing to greenhouse gas emission reductions). Market or government failure can reduce returns to payment schemes as benefits are often not adequately internalized or captured (Southgate and Wunder, 2009). ES schemes are identifying partial solutions to this dilemma by diversifying ES revenue streams (e.g. donor funds, market-based revenue sources, etc.) and also configuring project parameters to meet funding and stewardship requirements, best exemplified in the landscape-level and mosaic land use project examples.

\section{What do the results and case studies tell us about mechanisms and key conditions for scaling up PES beyond the project level to sub-regional and national schemes (e.g. REDD+)?}

Scaling up PES to sub-regional and national schemes carries functional benefits. Research findings indicate there are significant benefits of scaling beyond project-level, since hurdles and challenges identified at this level (e.g. high start-up costs, reducing transaction costs, measuring and monitoring performance, diversifying risks) could be 
reduced at broader scales. Scaling up PES may increase the ability to identify and mitigate leakage effects; i.e., the inadvertent displacement of activities damaging environmental service provision to areas outside the geographical zone of PES intervention (Robertson and Wunder, 2005).

National-level PES schemes exist in Costa Rica and Mexico, which can provide insight into efficacy and potential constraints. Ecuador's Socio Bosque programme seeks to incentivise conservation and alleviate poverty. Argentina's Federal Law 26.331 sets compensation for the environmental services provided by forests. The Costa Rican case study featured in Section 4 operates within the programmatic framework of FONAFIFO, Costa Rica's national PES programme, demonstrating how project-level activities can benefit from efficiencies in national monitoring as well as diversified sources of funding best coordinated through a government entity (e.g. gasoline tax and bilateral funds, in addition to carbon offset sales). Evaluation of ES service delivery and potential tradeoffs in future scenarios of climate and land use change is crucially needed in these national- and project-level PES schemes (Balvanera et al, 2012).

Bilateral funding arrangements are already being used to fulfill REDD+ objectives in Brazil, Indonesia and Guyana ${ }^{2}$ in exchange for verified forest carbon emissions reductions. These are national-level PES commitments that operate in much the same way the PES projects described in Sections 3 and 4 do, as they are pay-for-performance agreements, utilizing measurement and monitoring information, and rely on neutral financial intermediaries. These national-level PES schemes are fundamentally different from PES projects, however, in their ability to differentiate between incentive, policy, and disincentive (regulatory) interventions in order to meet their domestic REDD+ programme goals. There is a need to shift from either promoting markets or choosing government intervention, to applying a combination of instruments based on optimal combinations of market, hierarchical and cooperative systems for ecosystem service management (Engel, et al 2008).

Governments have a range of tools to apply to influence land use patterns. As one project in Section 3 demonstrated, fishermen found it unjustifiable that farmers polluting waters upstream should be compensated in order to better manage the resource. This raises not only questions of appropriateness of tools to apply (legal rules to constrain effluent and polluting land use practices may be as effective) but also questions of equity and fairness (paying polluters is rightly viewed as unfair by other users, and may undermine longer-term ES conservation objectives). While payments may change practices, they may not be the most appropriate tool. Environmental laws and enforcement may be better suited to these circumstances, and the monetization of ecosystem services cannot be expected to replace the role of regulatory mechanisms

2 These countries' bilateral commitment with Norway is valued at US\$ 1 billion each for Indonesia and Brazil and US\$250 million for Guyana. 
and enforcement (Braat and DeGroot, 2012). Further, governments must evaluate how to appropriately apply incentives and disincentives, in order to avoid overpaying for interventions solely based on evaluation of opportunity costs.

In many cases, a mix of financial incentives, disincentives and enabling measures will need to be applied to safeguard ecosystem services. A recent analysis of PES and REDD+ in the Brazilian Amazon discovered that combining existing command and control 'sticks' with PES 'carrots' could increase the political scope for reducing Amazonian deforestation by providing alternatives to the otherwise widely unacceptable and unequally distributed welfare gains or losses of applying any of the two instruments individually (Börner et al., 2011). In contexts of weak governance or lack of enforcement ability, the use of payments to change practices will likely be more effective than regulations. However, adequate governance mechanisms, enforcement capacity and tenure security are pre-conditions for effective operation of incentive schemes (Kissinger et al, 2012). Legal or legislative frameworks regulating public PES schemes can stimulate development of trustworthy markets and ensure good governance (Greiber, 2009). Concerns over government bias in Latin American jurisdictional legal arrangements are noted, particularly in cases of governments anticipating international payments for ES (Southgate and Wunder, 2007). Governments are encouraged to identify how to support local and national PES schemes, rather than how to maximize revenue from them. Though evidence suggests that user-financed programmes contain fewer confounding side objectives that can conflict with ES provision, such as poverty reduction and economic development, than with government-financed programmes (Wunder, Engle and Pagiola, 2008), governments have an important role to play in arbitrating between different users and stakeholders, and are in a better position to balance equity considerations in payments (particularly between different user groups of the same resource) than ES buyers.

\section{CONCLUSION}

Payments for ecosystem service schemes offer landholders a critical incentive to change land use practices and encourage stewardship. PES schemes offer a means to concurrently provide multiple non-financial benefits, directly leading to longer-term financial benefits for landholders, and often exceed the value of the financial payment. Some case studies reviewed indicate the long-term financial benefits to landholders as being so significant that even if the ES payments stopped, the improved practices would continue. However, PES is an imperfect mechanism at project level, since payments to landholders cannot always override competing economic and conflicting policy pressures. Further, incentives or payments may not always be the most appropriate tool to safeguard ecosystem services, and thus environmental laws and enforcement have a critical role to play.

Findings indicate that full compensation for all ES services is not necessary to safeguard environmental services. However, accounting for the full value of ecosystem services is 
important to articulate the value of benefits derived from ES and thus future potential costs if those ecosystem services are degraded or non-functioning.

Market mechanisms are an imperfect means of pricing the value of ecosystem services, particularly when enabling policies do not exist or are not consistent (e.g. policies committing to greenhouse gas emission reductions). ES schemes are piloting partial solutions to this dilemma by diversifying ES revenue streams (e.g. donor funds, marketbased revenue sources) and configuring project parameters to adjust to funding and stewardship requirements (best exemplified in the landscape-level and mosaic land use projects). However, governments can play a crucial role in providing the right enabling policies, and applying both incentives and disincentives, thus avoiding over-payment stemming from purely opportunity cost approaches to ES valuation.

The role of donor funds appears to be significant in incubating PES schemes. The use of intermediaries is critical in linking buyers to sellers, distributing non-financial benefits, and creating efficiencies in service delivery. There is a notable distinction between benefits and payments, and further research should investigate how landowners use ES funds, in order to understand the effect this has on safeguarding ecosystem services and livelihoods. For instance, benefits (e.g. technical assistance) can be targeted to support project goals, whereas payments are often left to the discretion of the landowner, and use of the funds may or may not promote ES stewardship.

Sub-regional or national-level PES schemes offer a viable means to address the most pressing financial challenges-e.g. high transaction costs, the need to diversify ES revenue sources due to under-performing carbon markets and lack of greenhouse gas emission reduction enabling policies, and to spread risk across multiple projects. Private sector engagement can still thrive in sub-regional or national-level PES schemes, particularly if projects are nested into broader scale PES initiatives, which deliver the enabling context to lower operational and financial risks for the private sector. Nationallevel and government-led PES schemes have the important added benefit over projectlevel PES activities of differentiating between incentive, policy, and disincentive (regulatory) interventions to influence land use patterns and safeguard ecosystem services. Implementation of this range of tools can overcome equity and efficiency concerns apparent in some project-level PES schemes. 


\section{REFERENCES}

Balvanera P, Uriarte M, Almeida-Leñero L, Altesor A, DeClerck F, Gardner T, Hall J, Lara A, Laterra P, Peña-Claros M, Silva Matos DM, Vogl AL, Romero-Duque LP, Arreola LF, Caro-Borrero ÁP, Gallego F, Jain M, Little C, de Oliveira Xavier R, Paruelo JM, et al. 2012. Ecosystem services research in Latin America: The state of the art. Ecosystem Services 2 (2012) 56-70.

Börner J, Wunder S, Wertz-Kanounnikoff S, Hyman G, Nascimento N. 2011. REDD sticks and carrots in the Brazilian Amazon: Assessing costs and livelihood implications. CCAFS Working Paper no. 8. CGIAR Research Program on Climate Change, Agriculture and Food Security (CCAFS). Copenhagen, Denmark.

Braat L, DeGroot R. 2012. The ecosystem services agenda: bridging the worlds of natural science and economics, conservation and development, and public and private policy. Ecosystem Services 1 (2012) 4-15.

DeGroot R, Brander L, van der Ploeg S, Costanza R, Bernard F, Braat L, Christie M, Crossman N, Ghermandi A, Hein L, Hussain S, Kumar P, McVittie A, Portela R, Rodriguez LC, ten Brinkm P, van Beukering P. 2012. Global estimates of the value of ecosystems and their services in monetary units. Ecosystem Services 1 (2012) 50-61.

Engel S, Pagiola S, Wunder S. 2008. "Designing payments for environmental services in theory and practice - an overview of the issues." Ecological Economics 65:663-674. doi:10.1016/j.ecolecon.2008.03.011.

Fisher B, Kulindwa K, Mwanyoka I, Turner RK, Burgess ND. 2010. Common pool resource management and PES: Lessons and constraints for water PES in Tanzania. Ecological Economics 69: 1253-1261.

Greiber T (Ed) 2009. Payments for ecosystem services. Legal and institutional frameworks. IUCN, Gland, Switzerland. xvi + 296 pp.

Grieg-Gran M, Porras I. 2012. Paying for watershed services: an effective tool in the developing world? IIED Briefing Paper.

Kandel S, Cuéllar N. 2011. Compensation for ecosystem services: Directions, potentials and pitfalls for rural communities. PRISMA-Salvadoran Research Programme on Development and Environment. San Salvador.

Kissinger G, Herold M, De Sy V. 2012. Drivers of deforestation and forest degradation: A synthesis report for REDD+ policymakers. Lexeme Consulting, Vancouver Canada, August 2012. 
Madsen B, Carroll N, Kandy D, Bennett G. 2011. Update: State of Biodiversity Markets. Washington, DC: Forest Trends, 2011. Available at:

http://www.ecosystemmarketplace.com/reports/2011_update_sbdm.

Murillo R, Kilian B, Castro R. 2011. Leveraging and sustainability of PES: Lessons learned from Costa Rica. In Rapidel B, DeClerck F, LeCoq JF, Beer J (Eds), Ecosystem services from agriculture and forestry: Measurement and payment. Earthscan, London.

Pagiola S, Rios AR, Arcenas A. 2008. Can the poor participate in payments for environmental services? Lessons from the Silvopastoral Project in Nicaragua. Environment and Development Economics, 13(3).

Pattanayak SK, Wunder S, Ferraro P. 2010. Show me the money: Do payments supply environmental services in developing countries? Review of Environmental Economics and Policy. 4 (2): 254-274. doi: 10.1093/reep/req006.

Peters-Stanley M, Hamilton K. 2012. Developing dimension: State of the voluntary carbon markets 2012. Ecosystem Marketplace \& Bloomberg New Energy Finance.

Rios AR, Pagiola S. 2009. Poor household participation in payments for environmental services in Nicaragua and Colombia MPRA Paper No. 13727, 2 March 2009 / 17:56.

Robinson BE, Holland MB, Naughton-Treves L. 2011. Does secure land tenure save forests? A review of the relationship between land tenure and tropical deforestation. CCAFS Working Paper no. 7. CGIAR Research Program on Climate Change, Agriculture and Food Security (CCAFS). Copenhagen, Denmark.

Southgate D, Wunder S. 2009. Paying for watershed services in Latin America: A review of current initiatives. Journal of Sustainable Forestry. Vol. 28.

Stanton T, Echavarria M, Hamilton K, Ott C. 2010. State of watershed payments: An emerging marketplace. Ecosystem Marketplace. Available online: http://www.foresttrends.org/documents/files/doc_2438.pdf

TEEB Foundations. 2010. In: Kumar P (Ed.), TEEB - The Economics of Ecosystems and Biodiversity (TEEB): Ecological and Economic Foundations. Earthscan, London.

Trivedi M, Costa D, Meneses-Filho L, Oakes N, Mitchell A, Strassburg B, Ortiz R, Seroa da Motta R, Guedes Pinto LF, Hall A, Ometto JP. 2012. Think PINC: Securing Brazil's food, water and energy with Proactive Investment in Natural Capital. Global Canopy Programme, Oxford, UK. 
Wunder S. 2008. Payments for environmental services and the poor: concepts and preliminary evidence. Environment and Development Economics, 13(3).

Wunder S, Engel S, Pagiola S. 2008. Taking stock: A comparative analysis of payments for environmental services programs in developed and developing countries. Ecological Economics 65:834-52.

Wunder S. 2005. Payments for environmental services: Some nuts and bolts. CIFOR Occasional paper No. 42. Bogor, Indonesia. 


\section{WORKING PAPERS}

\section{2}

141. Fortalecimiento de capacidades para la gestión del Santuario Nacional Pampa Hermosa: Construyendo las bases para un manejo adaptativo para el desarrollo local. Memorias del Proyect

142. Understanding rural institutional strengthening: A cross-level policy and institutional framework for sustainable development in Kenya

143. Climate change vulnerability of agroforestry

144. Rapid assessment of the inner Niger delta of Mali

145. Designing an incentive program to reduce on-farm deforestation in the East Usambara Mountains, Tanzania

146. Extent of adoption of conservation agriculture and agroforestry in Africa: the case of Tanzania, Kenya, Ghana, and Zambia

147. Policy incentives for scaling up conservation agriculture with trees in Africa: the case of Tanzania, Kenya, Ghana and Zambia

148. Commoditized or co-invested environmental services? Rewards for environmental services scheme: River Care program Way Besai watershed, Lampung, Indonesia

149. Assessment of the headwaters of the Blue Nile in Ethiopia

150. Assessment of the uThukela Watershed, Kwazaulu

151. Assessment of the Oum Zessar Watershed of Tunisia

152. Assessment of the Ruwenzori Mountains in Uganda

153. History of agroforestry research and development in Viet Nam. Analysis of research, opportunities and gaps

154. REDD+ in Indonesia: a historical perspective

155. Agroforestry and Forestry in Sulawesi series: Livelihood strategies and land use system dynamics in South Sulawesi

156. Agroforestry and Forestry in Sulawesi series: Livelihood strategies and land use system dynamics in Southeast Sulawesi

157. Agroforestry and Forestry in Sulawesi series: Profitability and land-use systems in South and Southeast Sulawesi

158. Agroforestry and Forestry in Sulawesi series: Gender, livelihoods and land in South and Southeast Sulawesi

159. Agroforestry and Forestry in Sulawesi series: Agroforestry extension needs at the community level in AgFor project sites in South and Southeast Sulawesi, Indonesia.

160. Agroforestry and Forestry in Sulawesi series: Rapid market appraisal of agricultural, plantation and forestry commodities in South and Southeast Sulawesi

2013

161. Diagnosis of farming systems in the Agroforestry for Livelihoods of Smallholder farmers in Northwestern Viet Nam project

162. Ecosystem vulnerability to climate change: a literature review

163. Local capacity for implementing payments for environmental services schemes: lessons from the RUPES project in northeastern Viet Nam

164. Seri Agroforestri dan Kehutanan di Sulawesi: Agroforestry dan Kehutanan di Sulawesi: Strategi mata pencaharian dan dinamika sistem penggunaan lahan di Sulawesi Selatan

165. Seri Agroforestri dan Kehutanan di Sulawesi: Mata pencaharian dan dinamika sistem penggunaan lahan di Sulawesi Tenggara

166. Seri Agroforestri dan Kehutanan di Sulawesi: Profitabilitas sistem penggunaan lahan di Sulawesi Selatan dan Sulawesi Tenggara

167. Seri Agroforestri dan Kehutanan di Sulawesi: Gender, mata pencarian dan lahan di Sulawesi Selatan dan Sulawesi Tenggara

168. Seri Agroforestri dan Kehutanan di Sulawesi: Kebutuhan penyuluhan agroforestri pada tingkat masyarakat di lokasi proyek AgFor di Sulawesi Selatan dan Tenggara, Indonesia

169. Seri Agroforestri dan Kehutanan di Sulawesi: Laporan hasil penilaian cepat untuk komoditas pertanian, perkebunan dan kehutanan di Sulawesi Selatan dan Tenggara 
The World Agroforestry Centre is an autonomous, non-profit research organization whose vision is a rural transformation in the developing world as smallholder households increase their use of trees in agricultural landscapes to improve food security, nutrition, income, health, shelter, social cohesion, energy resources and environmental sustainability. The Centre generates science-based knowledge about the diverse roles that trees play in agricultural landscapes, and uses its research to advance policies and practices, and their implementation that benefit the poor and the environment. It aims to ensure that all this is achieved by enhancing the quality of its science work, increasing operational efficiency, building and maintaining strong partnerships, accelerating the use and impact of its research, and promoting greater cohesion, interdependence and alignment within the organization.

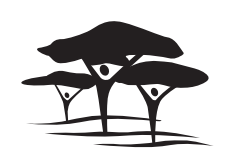

United Nations Avenue, Gigiri • PO Box 30677 • Nairobi, $00100 \cdot$ Kenya Telephone: +254207224000 or via USA +1 6508336645 Fax: +254207224001 or via USA +1 6508336646 Email: worldagroforestry@cgiar.org •www.worldagroforestry.org 